\title{
RESEARCH OF THE EFFICIENCY OF LITHUANIAN BANKS CREDIT GRANTING PROCESS
}

\author{
Ilona SKAČKAUSKIENE் $\mathbb{C}^{*}$, Anastasija BUSARĖVA \\ Department of Management, Faculty of Business Management, Vilnius Gediminas Technical University, \\ Saulètekio al. 11, 10223, Vilnius, Lithuania
}

Received 2 March 2021; accepted 1 April 2021

\begin{abstract}
Purpose - to evaluate the efficiency of the credit provision process of Lithuanian banks, to submit suggestions for improvement.

Research methodology - after the theoretical analysis of the efficiency of the credit granting process was developed, an empirical research using the methods of questionnaire survey and analysis of financial indicators was carried out.

Findings - efficiency is usually lost at the stages of consideration of application, conclusion of credit portfolio and risk assessment. These factors were distinguished from all efficiency reducing factors: time consuming processes, not automatized stages, insufficiently informed customer.
\end{abstract}

Research limitations - methods of analysis of scientific literature are limited, but they enable the analysis and identification of the efficiency of credit provision within the research.

Practical implications - the article evaluates the efficiency of credit provision by selected banks and proposes measures to streamline the process. By applying the proposed measures, banks could increase the efficiency of the credit granting process.

Originality/Value - previously, the effectiveness of credit granting process in Lithuanian banks has not been assessed.

Keywords: credit granting process, credit granting efficiency, financial indicators, Lithuanian banks, questionnaire survey.

JEL Classification: M10, M21, G32.

Conference topic: Contemporary Organizations Development Management.

\section{Introduction}

Reliable and effective financial sector encourages saving money and allows using it for most profitable investments in such way the financial sector supports innovation and economy. Credit granting system of commercial banks facilitate rational and effective distribution of funds within the economy, while that contributes to gross domestic product, as well as economic growth of the state. Not only the financial sector would suffer the consequences of reduced efficiency of bank credits, but also economic sector, which otherwise could receive investments that are funds received by user in a credit form. For this reason, efficiency of bank credit granting can be considered one of the main engines of economy growth in every country, therefore it is important to assure the efficiency of this service. Granting of credit is also important for the bank, because it is its most profitable activity. According to Grönroos (2020), efficiency is related to productivity, effectiveness and performance, these aspects can be successfully evaluated and enhanced - by identifying the stages, in which efficiency is lost, process can be rationalized and consequentially efficiency can be increased.

The paper aims to evaluate the efficiency of the credit provision process of Lithuanian banks, to submit suggestions for improvement. The research focuses on the efficiency of the credit granting process of "Sweedbank", "Danske bank", "Luminor" and "SEB" banks by tailoring set of proposals for increasing the efficiency of the credit granting process. After the theoretical analysis of the efficiency of the credit granting process was developed, an empirical research using the methods of questionnaire survey and analysis of financial indicators was carried out.

*E-mail: ilona.skackauskiene@vilniustech.lt

(C) 2021 Authors. Published by Vilnius Gediminas Technical University. This is an open-access article distributed under the terms of the Creative Commons Attribution (http://creativecommons.org/licenses/by/4.0/) License, which permits unrestricted use, distribution, and reproduction in any medium, provided the original author and source are credited. 
Results of empirical research have shown that in most cases the efficiency is lost when considering an application, building a credit portfolio and assessing risk. Among the factors that reduce efficiency were the following aspects: lengthy processes, non-automated possible stages, improper customer information. Banks are offered to inform customers about the process of filling in the credit applications, to maintain the reputation of banks, to automate possible processes, as this would reduce the probability of error and time costs.

The work consists of three main parts: theoretical part, methodology and analytical-research part. First, the theoretical aspects of credit provision and the theoretical aspects of the efficiency of the credit provision process are analyzed. The second part presents the methodology of credit efficiency assessment, justifies the chosen research methods - the analysis of financial indicators and a questionnaire survey of employees working with credit. Finally, the efficiency of the credit provision process of selected banks is analyzed according to the developed methodology. Summarizing the results of the research, a set of suggestions for the rationalization of the process and conclusions are presented.

\section{Theoretical analysis of credit granting}

Granting of credit to business clients and natural persons is a process comprised of specific stages. After summarizing literature analysis (e. g. Miloviené, 2009; Assef et al., 2019) we distinguish 8 such stages: conclusion of portfolio of credit applications, consideration of application, risk assessment, conclusion of credit agreement, granting of credit, repayment control, repayment of credit.

Granting of credit is done according to specific procedure, first of all, bank carries out the analysis of credit worthiness and reveals risk factors that could lead to failure to fulfil the obligations till the date determined by bank, evaluates the probability of repayment in timely manner (Bals \& Turkulainen, 2017). Determining of creditworthiness of credit recipient is inseparable part of bank procedures carried out to determine the possibility of granting a credit (Jucevičiūte, 2019; Shevchuk, 2017). Experience indicates that many banks form credit committees whose main objective is analysis of clients' applications for opening credit accounts and receiving credits (Agarwal et al., 2018). Credit granting departments do not accept client's applications for credit granting without the conclusions of these committees. It should be noted that credit is usually granted after presenting standard documents, describing the purpose, size and conditions of the credit as well as creditworthiness of client.

Irrespective of weather credit is granted to natural person, or business client - process must be effective. Financial methods should also be used in order to acquire reliable information for evaluating the efficiency of process. Efficiency is the aim, on which bank managers base their management decisions. Scientific literature doesn't provide one general solution of how and what indicators and models should be used of assessment of efficiency of bank's economic activity, however literature sources (Doan et al., 2018; Lapinskaitė \& Kvedarytė, 2020; Galinienė \& Mašalaityte், 2007) usually mention analysis of financial reports that analyse indicators describing efficiency of activity. Such indicators are calculated according to production cycle, funds and stages circulated in that process. According to database of financial analysis, efficiency of bank activity can be assessed and conclusion about profitability and perspectives can be made. Bank's financial analysis provides valuable information for manager when assessing the efficiency of activity (Jasevičienè, 2013). Object of assessment of financial analysis is bank's financial activity and its results that are reflected in bank's financial reports. According to Jasevičienè (2013), financial analysis is important measure for explaining and improving financial state of a bank and for optimizing the control of processes, it also can be important form of control of bank's activity. Since the credit is issued by bank, examination of credit efficiency is related to examination of efficiency of bank activity.

Efficiency of credit process can be assessed by calculating financial indicators, i.e. by carrying out financial analysis, but efficiency can also be assessed at each stage of granting of credit by carrying out non-financial analysis, which is more difficult to do because of abstractness of service and lack of unified assessment system (Tarasova, 2017). Efficiency of every stage of credit service provision should be assessed during the non-financial analysis:

- Efficiency of conclusion of credit application portfolio is indicated by these aspects: Did employee correctly establish credit aims, sum and conditions. If employee failed to provide clear information to the client, client might encounter difficulties in repaying the credit. Efficiency of this stage also depends on the method the client used to fill out the application (Mačerinskienè \& Ivaškevičiūtè, 2000).

- At the stage of consideration of application and making of decisions related to granting of credit, efficiency is indicated by the time it took for these processes to be completed by employees. This stage can clearly reveal the deficiency of time usage, because lack of time can make a client choose a different bank and refuse the service and even accept inferior credit granting conditions in order to be granted the credit sooner (Yuen \& Thai, 2017).

- According to Valvonis (2004), risk assessment is one of the most important stages, because if it is carried inappropriately, credit might be granted to unreliable person and not repaid in a timely manner. Stage of risk assessment can be assessed during the period of credit repayment: what percentage of clients fulfilled their obligations in a timely manner. 
- At the time of conclusion of credit agreement, efficiency is reflected by the time in which the agreement was concluded. Time needed for this operation is affected by standardization. In such case, efficiency can be assessed according to reduction of costs, i.e. how much the labor costs of manager, lawyer reviewing the agreement and providing the visa are reduced by using standardized agreement.

- According to Milovienè (2008), efficiency of credit repayment and control stage is reflected by the ratio between achieved goals and received results.

To summarize, it can be stated that there is no consensus about assessment of efficiency of every stage, however each stage affects the efficiency of service provisions, therefore it should be properly implemented, constantly analyzed and improved.

\section{Methodology of empiric study}

Assessment of efficiency of credit granting process in this article is carried using methods of analysis of financial indicators and questionnaire. These methods created the conditions for determining the efficiency of analyzed process, i.e., to identify the stages of credit granting process in which the efficiency is lost and the factors that affect this process.

Efficiency is inseparable aspect of activity in any bank, i.e., bank's success depends on efficiency of service provision, therefore it should be properly assessed (Koutsothanassi, 2017). According to Jasevičienè (2013), analysis of efficiency of activity is important measure for explaining and improving bank's financial situation and optimizing process management. According to Tsai et al. (2016), analysis isn't effective when reasons of efficiency reduction and stages at which the efficiency was reduced are identified, it becomes effective when measures for increasing efficiency are proposed.

Assessment of efficiency of credit granting process was carried out with main banks operating in Lithuania: "Swedbank"; "Danske bankas"; "SEB"; "Luminor". Analysis was carried out using financial reports of banks. These indicators are assessed during the financial analysis:

1. Operating margin. Gross margin reflects bank's ability to profit from its activity.

2. Return on equity. Return on equity is indicator of net profit compared to equity capital of organization.

3. Return on assets - coefficient indicating the size of profit per price of one unit of capital. It describes the efficiency of use of company's assets.

4. Return on investments - payback ratio. This indicator reflects profitability or unprofitability of investment.

5. Cost-to-income ratio - indicator reflecting the efficiency of business.

6. Coefficient of profit per share (EPS) indicates size of company's profit per ordinary share.

Questionnaire was provided to be completed by bank's employees in order to determine the aspects that reduce the efficiency of credit granting and at which stages of credit granting process they appear. Data gathered during this questionnaire was structured by distinguishing main aspects of efficiency reduction in stages of credit granting. Formula of Pranulis and Dikčius (2012) was used for determining the sample size of questionnaire (92 proc. probability with 8 proc. error):

$$
n=\frac{z^{2} \times p \times(1-p)}{e^{2}},
$$

where: $n$ - sample size; $z$ - unit of measurement of standard error under normal distribution; $p=50$ proc. - proportion of the whole, used for describing the properties of interest; $e$ - error of selection (5\%).

According to data of website of official statistics, Swedbank has 2035 employees, Danske bank - 3974, SEB Bank - 1572, Luminor bank - 1134, overall, there are 8715 employees working in these selected banks. There are no precise data about how many employees work with credit granting procedures, but according to Miloviené (2009), such employees comprise $15 \%$ of the number of all employees, i.e. 1307 employees in selected banks, while size of sample is 134 employees.

Empirical study was carried out in 3 stages: firstly, financial examination of activity was carried out, after that, questionary was completed by employees and finally, analysis and synthesis of results was carried out. Analysis of financial indicators of efficiency of credit granting activity is important measure for explaining current bank's financial situation and optimizing management of credit granting process. Questionnaire completed by employees allowed to identify efficiency reducing factors and to determine the stages in which they appear. Questionnaire supplemented the results received from financial analysis. Set of efficiency enhancing suggestion were prepared according to results of analysis and questionnaire. 


\section{Results of empirical study}

\subsection{Results of analysis of financial indicators}

Granting of credit is bank's most profitable activity, therefore it greatly affects bank's financial indicators, while financial indicators of bank activity consequentially, directly or indirectly reflect the efficiency of process of credit granting. Additional corelative analysis was carried out in order to determine the strength of connection between the credit granting profit and net profit. Results show that strong corelative connection between stock profit and net profit exists in all banks. In case of selected banks, we see that highest dependency of net profit on credit profit is in SEB bank, but this connection is very strong in other banks as well. Based on the results it can be stated that efficiency of credit activity has high impact on net profit and consequentially on financial indicators.

It should be noted that period of analysis of financial indicators was last 5 years, however only 4 years of Luminor bank was analyzed, because this bank started its operation in Lithuania 4 years ago. Numbers are presented in $\mathrm{x}$ 1000 (in thousands) of euro, for convenience. Results of operating margin are presented in Table 1.

Largest margin was found un "SEB" bank, it can be assumed that this is because "SEB" bank is one of the leaders according to number of granted credits and offers lower interest payments than its competitors. Smallest operation margin was found in "Danske" bank. Suspected reason for this is that "Danske" bank was related to money laundering incident and lost many clients, which forced it to change its operating strategy.

According to average statistics, return on equity should be around 10-12\%. Indicators of "SEB", "Swedbank" and "Danske" bank are satisfactory, while in "Luminor" bank they are lower than norm (see Table 2). Reason for such situation in "Luminor" bank is that "Luminor" bank started its activity in 2016 and new activity requires a lot of investments.

Analysis of return on assets (see Table 3) revealed that "Swedbank" uses its assets most effectively, while lowest efficiency was found in "Luminor" bank.

We can see that "Swedbank" effectively attracts and distributes acquired resources - profitability of "Swedbank" surpasses profitability of competitors. We could state that it is partially because this bank has a lot of clients, successfully allocates its assets, is effective in granting credits and has profitable contracts. Low profitability indicators of "Luminor" can be related to insufficient number of clients.

Results of return on investments are presented in Table 4. Investments in selected banks are profitable, except of activity of "SEB" bank in 2015. Profitability of investments in "SEB", "Dankse" and "Luminor" banks is growing, it means that net profit increased while costs decreased. While net profit of "Swedbank" increased, profitability of investments suddenly decreases in 2019 , from $132 \%$ in 2018 to $105 \%$ in 2019 , it was caused by increased costs when bank invested in sustainable assets.

According to banking practices, satisfactory value of ratio between costs and income (CIR) is up to $50 \%$. Activity of "Swedbank", "Danske" bank and "Luminor" is efficient, CIR ratio of these banks is up to 50\% (see Table 5). While activity of "SEB" isn't unprofitable, reduced efficiency was noticed, sums of newly granted credits were smaller because of more conservative behavior of clients when evaluating potential risk of business. However, in terms of analyzed indicator situation became better in 2019 because of increase in size of portfolio, which was conditioned by increased portfolio of current investments of private and business clients. Increase of income in "SEB" bank in 2019 was conditioned by increasing credit margins and increased net commission income (indicating the increase in client activity).

Results of analysis of profit per share coefficient (EPS) are presented in Table 6. Shares of "Swedbank", "Danske", "SEB" and "Luminor" are profitable. Highest profit per share was found in "Swedbank", this bank has largest market share, concludes successful contracts and grants credits effectively when compared to other selected banks.

Analysis of financial indicators helped to evaluate the efficiency of bank activity and reflected the aspects of efficiency of credit granting process. Calculations show how "Swedbank" effectively attracts and allocates acquired resources. Profitability of "Swedbank" exceeds profitability of competitors, this is conditioned by effective granting of credits, larger number of clients, successful distribution of assets and profitable contracts. Analysis revealed that "Swedbank" has large margin of activity, satisfactory indicator of net profit, this bank uses its assets most successfully of all selected banks. Ration of costs and income indicates efficiency of operation, this indicator is also confirmed by profitability of bank's shares.

Analysis revealed that "Danske" bank has smallest margin of activity of all selected banks, but net profit indicator and asset usage return coefficients are satisfactory, profitability of shares is growing, which indicates increasing efficiency of bank's activity, this is also confirmed by CIR indicator, bank's shares are profitable. Conclusion can be made that efficiency of bank's activity should be increased by increasing the efficiency of credit granting activity.

Analysis indicates that "SEB" is categorized by largest margin of activity of all selected banks, indicator of financial return ROE is at acceptable norm as is the return on company's assets. Profitability of company's investments is growing, but CIR indicator shows decrease in efficiency. Decreased efficiency of "SEB" bank is caused by decrease in sum of newly granted credits in 2019. Increase of income of "SEB" bank is caused by increasing credit margins and increased net profit of commission, which grew because of increase of client activity. 
Table 1. Comparison of operation margin of banks (source: created by authors)

\begin{tabular}{|l|c|c|c|c|c|}
\hline Bank & 2015 & 2016 & 2017 & 2018 & 2019 \\
\hline Swedbank & $72.96 \%$ & $60.53 \%$ & $59.85 \%$ & $59.64 \%$ & $54.09 \%$ \\
\hline Danske Bank & $15.3 \%$ & $20.9 \%$ & $21.9 \%$ & $17.2 \%$ & $17.3 \%$ \\
\hline SEB & $60 \%$ & $85.3 \%$ & $78.3 \%$ & $100 \%$ & $92.7 \%$ \\
\hline Luminor & - & $28.8 \%$ & $12.2 \%$ & $47.9 \%$ & $22.1 \%$ \\
\hline
\end{tabular}

Table 2. Comparison of return on equity of selected banks (source: created by authors)

\begin{tabular}{|l|c|c|c|c|c|}
\hline Bank & 2015 & 2016 & 2017 & 2018 & 2019 \\
\hline Swedbank & $10 \%$ & $9.7 \%$ & $14.4 \%$ & $15.7 \%$ & $14.2 \%$ \\
\hline Danske Bank & $13.4 \%$ & $13.5 \%$ & $13.6 \%$ & $12.3 \%$ & $11.7 \%$ \\
\hline SEB & $7.6 \%$ & $11.9 \%$ & $12.2 \%$ & $13.7 \%$ & $14.9 \%$ \\
\hline Luminor & - & $4.8 \%$ & $1.9 \%$ & $7 \%$ & $3.1 \%$ \\
\hline
\end{tabular}

Table 3. Comparison of return on assets of selected banks (source: created by authors)

\begin{tabular}{|l|c|c|c|c|c|}
\hline Bank & 2015 & 2016 & 2017 & 2018 & 2019 \\
\hline Swedbank & $10 \%$ & $9.7 \%$ & $14.4 \%$ & $15.7 \%$ & $14.2 \%$ \\
\hline Danske Bankas & $13.4 \%$ & $13.5 \%$ & $13.6 \%$ & $12.3 \%$ & $11.7 \%$ \\
\hline SEB & $7.6 \%$ & $11.9 \%$ & $12.2 \%$ & $13.7 \%$ & $14.9 \%$ \\
\hline Luminor & - & $4.8 \%$ & $1.9 \%$ & $7 \%$ & $3.1 \%$ \\
\hline
\end{tabular}

Table 4. Comparison of return on investments of selected banks (source: created by authors)

\begin{tabular}{|l|c|c|c|c|c|}
\hline Bank & 2015 & 2016 & 2017 & 2018 & 2019 \\
\hline Swedbank & $135.4 \%$ & $124.9 \%$ & $120.7 \%$ & $132.7 \%$ & $105.1 \%$ \\
\hline Danske Bank & $105.7 \%$ & $101.6 \%$ & $102.01 \%$ & $103.6 \%$ & $107.3 \%$ \\
\hline SEB & $0.78 \%$ & $115.3 \%$ & $123.5 \%$ & $133.9 \%$ & $152.5 \%$ \\
\hline Luminor & - & $176.7 \%$ & $154 \%$ & $155 \%$ & $156.2 \%$ \\
\hline
\end{tabular}

Table 5. Comparison of CIR of selected banks (source: created by authors)

\begin{tabular}{|l|c|c|c|c|c|}
\hline Bank & 2015 & 2016 & 2017 & 2018 & 2019 \\
\hline Swedbank & $48.4 \%$ & $43.5 \%$ & $42.4 \%$ & $41.6 \%$ & $45.4 \%$ \\
\hline Danske Bank & $48.6 \%$ & $49.6 \%$ & $49.5 \%$ & $49.1 \%$ & $48.2 \%$ \\
\hline SEB & $65.1 \%$ & $70.1 \%$ & $63.5 \%$ & $74.6 \%$ & $60.7 \%$ \\
\hline Luminor & - & $16.3 \%$ & $9.7 \%$ & $14.1 \%$ & $14.6 \%$ \\
\hline
\end{tabular}

Table 6. Comparison of EPS of selected banks (source: created by authors)

\begin{tabular}{|l|c|c|c|c|c|}
\hline Bank & 2015 & 2016 & 2017 & 2018 & 2019 \\
\hline Swedbank & 0.006 & 0.0064 & 0.0068 & 0.0077 & 0.0074 \\
\hline Danske Bank & 0.0044 & 0.0051 & 0.0051 & 0.0047 & 0.0050 \\
\hline SEB & 0.0039 & 0.0061 & 0.006 & 0.006 & 0.007 \\
\hline Luminor & - & 0.0065 & 0.0037 & 0.015 & 0.015 \\
\hline
\end{tabular}

Analysis of "Luminor" bank provided this data: shares are profitable, margin of activity is satisfactory, but net profit indicator is lower than acceptable norm the same as coefficient of company's return on asset usage. CIR indicator revealed that bank's activity isn't unprofitable. According to received data it can be concluded that activity isn't unprofitable, but efficiency of "Luminor" bank is decreased, which is related to insufficient number of clients. 


\subsection{Results of employee questionnaire}

In order to identify the stages at which the efficiency is lost and factors the cause these losses, employee questionnaire was carried out. Overall, 134 employees completed the questionnaire, which consisted of 13 questions.

First question was meant to identify the bank in which the employee is employed. It was found that largest part of participants works at "Danske" (32\%) bank and "Swedbank" (31.3\%). Second question of the questionnaire was designed to select only those employees who work in field of credit granting, 6 respondents indicated to be working in a different field, therefore, only the answers of 128 respondents were analyzed. Third question was used to determine the most common method of filling out an application to receive a credit. It revealed that $57 \%$ fill out the application in the bank. Filling out of application on the website is faster and more convenient, but only $34 \%$ of clients use this method. Therefore, fourth question was meant to reveal if clients are well informed about such possibility. Results show that $53.1 \%$ of employees think that more effort should be put in to informing of clients.

Most important of aspect of efficient process is terms, therefore it was aimed to find out how much time does consideration of application take. Results are ambiguous, distributed very unevenly. $14 \%$ of responders indicated that consideration takes from two days to a week, $21 \%$ - from eight days to two weeks, $13 \%$ - more than two weeks, $52 \%$ - varied time. Such results could be conditioned by the fact that consideration of application depends on various aspects: type, size of credit, client's guarantees and so on.

Risk assessment is important stage requiring a lot of time and caution (Lim et al., 2019); therefore, employees were asked if in their view the process could be more automatized in order to complete it faster and more efficiently. $57.8 \%$ of employees think that process at the stage of risk assessment should be more automatized, $23.4 \%$ of employees think that process is automatized enough, $18.8 \%$ employees have no opinion about this question. According to the answers we can conclude that risk assessment should be more automatized in order to save time and increase efficiency.

Stage of risk assessment is affected not only by speed, bet al.o the quality of process completion. Respondents were asked, how would they rate the efficiency of risk assessment ( 1 - completely ineffective to 5 - very effective). $27 \%$ of respondents gave an average score to efficiency of risk assessment system. However, most of respondents $(52 \%)$ chose the score "good", while $21 \%$ gave maximum score. It should be noted that not one respondent has selected scores "bad" and "very bad". It can be stated that essentially, risk assessment process is well optimized.

Respondents were asked if number of employees should be reduced, because in practice, excess of employees can reduce the efficiency. However, most employees $(83 \%)$ responded that it is really not necessary to reduce the number of employees. Respondents who said that the number of employees should be reduced (14\%), had an opportunity to comment on their choice, many mentioned higher degree of automatization of process.

Another question was meant to reveal if more standardized credit agreements should be used in order to reduce the time costs of concluding the agreement. According to answers it can be concluded that agreements are standardized enough.

Tenth question of the questionnaire was related to seventh, i.e. at the time of answering the question, respondents were asked to evaluate how frequently they encounter problems at the stage of credit repayment. This is directly dependent on efficiency of credit risk assessment. As expected, there was correlation with answers to seventh question, even $56 \%$ stated that problems are rare, while $20 \%$ said that they are very rare, however, $23 \%$ of workers think that problems are quite frequent at the stage credit repayment. Respondents had a chance to explain their choices, employees mentioned that some problems are caused by poor risk assessment, however, it is important to keep in mind that problems are caused not only by poor assessment of risk, but also by unexpected circumstances.

Not only the identification of stages in which the efficiency is lost is important for increasing the efficiency of process, but also finding the aspects that affect the loss of efficiency. Answers of respondent revealed that main cause of efficiency decrease is time consuming processes $(26 \%)$ and possible not automatized stages (18\%). It can be assumed that partially not automatized processes lead more time consuming processes, also one of the most selected answers is inappropriate informing of users.

Last question was free form, and every respondent could express their insights about increasing the efficiency of credit granting process. Respondents highlighted such aspects: higher degree of automatization of processes, introduction of new credit product, systemic modernization of existing credit products, minimizing of inefficient systems of credit granting, implementation of new technologies, better informed clients, improvement and automatization of risk assessment system.

To summarize the data acquired from questionnaire it can be stated that efficiency is usually lost at the stage of consideration of application, conclusion of credit portfolio, risk assessment. These aspects were distinguished among efficiency decreasing factors: time consuming processes, not automized stages, inappropriate informing of clients. Employees noted that user should be better informed about possibility to fill out the application online, also risk assessment could be more automatized. 


\section{Assessment of efficiency of credit granting process and suggestions for improvement}

According to Tsai et al. (2016), analysis isn't effective when reasons of efficiency reduction and stages at which the efficiency was reduced are identified, it becomes effective when measures for increasing efficiency are proposed. Study helped to determine the efficiency of credit granting process, allowed to identify the stages during which efficiency is lost and reasons for such loss. Set of suggestions for rationalization of process was created according to results of the study. Suggestions were proposed for every stage of credit granting process. Set of suggestions was concluded in 4 stages: 1. Identification of stage of credit granting; 2. Assessment of credit granting efficiency; 3. Identification of aspects that reduce the efficiency of credit granting. 4. Conclusion of suggestion list.

Although in literature stages of credit granting are defined differently, the stages proposed by Milovienè (2008) unify the opinions of many authors and reflect the process well. During the analysis, credit process was broken down into eight stages (Milovienè, 2009): 1. Conclusion of credit application portfolio; 2. Consideration of application; 3. Risk assessment; 4. Making of decisions concerning granting of credit; 5. Conclusion of credit agreement; 6 . Granting of credit; 7. Repayment control; 8. Credit repayment. Suggestions were prepared for stages in which efficiency reducing factors were identified.

At the time of conclusion of credit agreement, efficiency is indicated by the time it took to conclude the agreement. Required time period depends on the method of filling the application. During the questionnaire, employees indicated that only $34 \%$ of clients fill out the application online, though filling of application online increases the efficiency of the stage, saves time for client and bank. 53.1\% of employees indicated that clients aren't well informed about possibility of filling out of application online. Therefore, it is suggested to use various methods of informing the client: by using billboards in premises of the bank, by providing information for the clients in a visible area of bank's website also bank employees should inform the clients in branches of bank about filling of application online.

Stage of risk assessment is one of the most important stages of credit granting process because efficiency of credit from bank's perspective depends on profit of activity, if risk is poorly assessed, client might not be able to repay the credit and in such case, there can be no talk about efficiency of process. Analysis revealed that stage of risk assessment is distinguished as one of the main stages in which efficiency is lost. During the study, many employees noted that stage of risk assessment should be more automatized, that would speed up credit granting process, reduce bank's costs and increase the efficiency. It is suggested to create computer analyzed form, in which the client would answer question and provide required guarantees, if client exceeds pre-determined number of points, he is added to risk group, in such case, bank employee would analyze this case more thoroughly, while when client provides all required guarantees and isn't added to risk group, employee will only need to confirm received data.

Most important aspect of decision-making stage is time required for the bank to present the answer to the client. In this case, client's perception of credit granting efficiency has an effect on bank's perception of credit granting efficiency, because at this stage, long waiting time can cause client to perceive it as non-efficient provision of service and make him refuse the service in selected bank, in such case bank's credit efficiency would be also decreased. This stage of credit granting is affected by 3 previous stages. It means that if these stages will be completed appropriately, there should be no difficulties at the stage of consideration of application with condition that there is correct number of employees. During the questionnaire, employees noted that there is no need for reduction of number of employees, therefore, current number of employees should be retained by offering favorable working condition to the employees.

Credit repayment is the main stage reflecting the efficiency of whole process. Results of the study revealed that $76 \%$ of employees think that problems rarely occur at this stage, other respondents had an opportunity to elaborate on their answers. Employees mentioned that sometimes they encounter problems caused by poor risk assessment, but it is important to mention that problems are caused not only by poor assessment of risk, but also by unexpected circumstances. This stage is directly affected by risk assessment stage, therefore, if this stage would be automatized more by using computer analyzed risk assessment form, it would increase the efficiency of credit repayment.

Analysis of results of financial data research revealed decreased return on assets caused by insufficient number of clients applying for credit, while results of activity margin analysis revealed that such situation can be caused by such event as loss of bank's reputation, which causes client to lose their trust in bank and choose another establishment. Therefore, in order to not lose clients, it is not only important to assure efficient credit granting process, but also to maintain the reputation of the bank. It is suggested to maintain reputation of bank by providing quality services to the customers, highlighting bank's reliability, stability, openness of business, transparency of activity and social responsibility.

Efficiency of bank credit process depends on sum of the credit. Financial analysis revealed reduced efficiency of activity caused by reduction of sum of newly granted credits after clients evaluated present risks. Larger credits are usually taken for housing or business. It is suggested to encourage clients to take larger credits by offering more favorable conditions. For example, credit for young family: more favorable conditions caused a rise in number of young clients and sums of credit, it resulted in increased efficiency of credit granting process. It is also suggested provision of individual services to business clients, for example, in case of necessity, extend the payment term or postpone the payments, this would reduce business related risks and clients would be more willing to take credit. 
It is also suggested to offer credits without complicated conditions, this way the efficiency of credit granting would be increased from perspective of the client and he would be willing to take larger credit sums, this would lead to increase of bank's credit granting efficiency.

\section{Conclusions}

Credit is granted by bank, therefore, examination of credit granting efficiency is inseparable from examination of bank's activity. Scientists (Koch \& MacDonald, 2015; Gudelyte \& Valužis, 2013) highlight that it is necessary to analyze the efficiency of credit granting process itself, therefore, questionnaire was presented to the employees working with credit grating, which allowed to identify factors that reduce the efficiency and determine the stages in which these factors appear. Results of questionnaire supplemented the results of financial analysis and helped to create a set of suggestions.

To summarize the results received from questionnaire it can be stated that efficiency is usually lost at the stages of consideration of application, conclusion of credit portfolio and risk assessment. These factors were distinguished from all efficiency reducing factors: time consuming processes, not automatized stages, insufficiently informed customer.

During the analysis of financial indicators, bank's efficiency was assessed. During analysis and interpretation of results, aspects reducing the efficiency of credit granting process were identified. To summarize the results of financial analysis it can be stated that activity of "Swedbank" is most efficient in terms of credit granting - its credit granting profitability is higher than of its competitors, "Swedbank" has more clients, allocates its assets successfully, concludes profitable contracts. Financial analysis of "Danske bank" revealed that bank lost clients because of bad reputation and its credit granting efficiency decreased significantly. Efficiency decrease of "SEB" bank is caused by decrease of sums of newly granted credits. Credit sum has significant impact on efficiency of credit granting process. Decreased efficiency of "Luminor" bank is related to insufficient number of clients.

The research assessed the efficiency of the credit granting process, identified the stages where efficiency was lost and for what reasons. Based on the results of the study, a set of suggestions was developed for streamlining the process. At each stage of credit provision, measures are proposed to improve the efficiency of credit provision. Banks are offered to better inform customers about the ways to fill in credit applications, to automate possible processes, as this would reduce the probability of error and time costs. Banks are also being offered to increase the efficiency of lending by encouraging customers to charge higher amounts, as the efficiency of the bank depends on the amount of credit, so offering clear conditions for mortgages and individual conditions for business loans would increase efficiency.

The paper evaluates the efficiency of credit provision by selected banks and proposes measures to streamline the process. By applying the proposed measures, banks could increase the efficiency of the credit provision process.

\section{References}

Agarwal, S., Chomsisengphet, S., Mahoney, N. \& Stroebel, J. (2018). Do banks pass through credit expansions to consumers who want to borrow? The Quarterly Journal of Economics, 133(1), 129-190. https://doi.org/10.1093/qje/qjx027

Assef, F. S., Steiner, M., Steiner, P. ,\& Franco, D. (2019). Classification algorithms in financial application: credit risk analysis on legal entities. IEEE Latin America Transactions, 17(10), 1733-1740. https://doi.org/10.1109/TLA.2019.8986452

Bals, L., \& Turkulainen,V. (2017). Achieving efficiency and effectiveness in purchasing and supply management: Organization design and outsourcing. Journal of Purchasing and Supply Management, 23(4), 256-267. https://doi.org/10.1016/j.pursup.2017.06.003

Doan, A. T., Lin, L.-K., \& Doong, S.-C. (2019). What drives bank efficiency? The interaction of bank income diversification and ownership. International Review of Economics \& Finance, 55, 203-219. https://doi.org/10.1016/j.iref.2017.07.019

Galinienè, B., \& Mašalaitytè, L. (2007). Verslo vertinimo kokybei turinys įtakos finansinès analizès apsketai. Ekonomika, 77, 7-24. https://doi.org/10.15388/Ekon.2007.17597

Grönroos, C. (2020). Service marketing research priorities: service and marketing. Journal of Services Marketing, 34(3), $291-298$. https://doi.org/10.1108/JSM-08-2019-0306

Gudelytè, L. \& Valužis, M. (2013). Banko veiklos auditas: banku valdymo ir ju priežiūros pagrindai: žinynas. Viešoji ịstaiga Socialinių mokslų kolegija.

Jasevičienè, F. (2013). Komercine bankininkystė: analizè ir vertinimai: monografija. Vilniaus universiteto leidykla.

Jucevičiūtè, E. (2019). Komerciniu banku kreditavimo paslaugu rizika ir jos valdymas. VDU.

Koch, T. W., \& MacDonald, S. S. (2015). Bank management. Cengage Learning.

Koutsothanassi, E. B. (2017). Examining the relationships among service features, customer loyalty and switching barriers in the Greek banking sector. International Journal of Quality and Service Sciences, 9(3/4), 425-440.

https://doi.org/10.1108/IJQSS-02-2017-0013 
Lapinskaite, I., \& Kvedaryte, R. (2020, 12 February). Finansinių technologijų ịtakos komercinių bankų pelningumo rodikliams tyrimas. In Proceedings of the 23th Conference for Junior Researchers "Science - Future of Lithuania" "Economics and management" (pp. 1-10). Vilnius, Lithuania. VGTU leidykla Technika. https://doi.org/10.3846/vvf.2020.029

Lim, C., Kim, M.-J., Kim, K.-H., Kim, K.-J., \& Maglio, P. (2019). Customer process management: A framework for using customer-related data to create customer value. Journal of Service Management, 30(1), 105-131. https://doi.org/10.1108/JOSM-02-2017-0031

Mačerinskienè, I., \& Ivaškevičiūtè, L. (2000). Banko paskolų portfelio valdymo tyrimo metodologiniai aspektai. Socialiniai mokslai, (5), 41-53.

Milovienè, L. (2008). Kreditavimo sistema. Kreditavimo produktai, procesas bei procedūros. Mykolas Romeris University.

Pranulis, V. P., \& Dikčius, V. (2012). Rinkodaros tyrimai: teorija ir praktika. Vilniaus universitetas.

Shevchuk, D. (2017). Kredity fizicheskim litsam (ipoteka, avtokredit, netselevye kredity). Litres.

Tarasova, T. Yu. (2017). Spetsificheskie osobennosti bankovskogo produkta i uslugi. Nauchnye vedomosti Belgorodskogo gosudarstvennogo universiteta. Seriya: Ekonomika. Informatika, 41.2(251).

Tsai, S. B., Li, G., Wu, C. H., Zheng, Y., \& Wang, J. (2016). An empirical research on evaluating banks' credit assessment of corporate customers. SpringerPlus, 5(1), 1-13. https://doi.org/10.1186/s40064-016-3774-0

Valvonis, V. (2004). Kredito rizikos valdymas banke. Pinigu studijos, (4), 57-82.

Yuen, K. F., \& Thai, V. (2017). Service quality appraisal: a study of interactions. Total Quality Management \& Business Excellence, 28(7-8), 730-745. https://doi.org/10.1080/14783363.2015.1114881 